\title{
The Untapped Mystery and Potentials in Termites
}

\author{
Beck Arebamen Akhiwu ${ }^{1 *}$ and Jinming Ray Williams ${ }^{2}$ \\ ${ }^{1}$ Department of Plant Pathology, Nematology and Entomology, University of Idaho, Moscow, Idaho, USA \\ ${ }^{2}$ Professor and Graduate Program Director, Insect Ecology and Plant-Insect Interactions, Appalachian State University, USA
}

*Corresponding author: Beck Arebamen Akhiwu, Department of Plant Pathology, Nematology and Entomology, University of Idaho, 132 Falls Avenue West, Apt C302, Twin Falls, Moscow, Idaho, USA.

Received Date: August 07, 2020

Published Date: August 14, 2020

\begin{abstract}
This review is aimed at reawakening entomologists and researchers in exploring numerous beneficial potentials in termites rather than just focusing on the destructive nature of termites. Termites are one of the most hated insects in the world because of their destructive nature. Several heavy inorganic chemicals, such as organochlorine (cyclodiene) insecticides, have been developed for termites control. This review indicates some of the benefits, such as medicinal, food, intellectual, spiritual and beautiful scenery architectural works of termites. This review shows that termites could be rear for positive economic values. The economic importance of termites is not yet well explored.
\end{abstract}

\section{Introduction}

Termite (Termitoidae) is one of the most underrated and disrespected insects. The positive impacts of termites have not yet well explored. Termites belong to Order: Blattodea and Ifraorder: Isoptera commonly referred to as destroyer of wood or white ants but not white [1]. Termites are eusocial insects. They live in a colony, only some individual is able to reproduce. They are well behaved, meticulous and highly organized insects. They exhibit a division of labor with individuals taking up different roles, such as defense or foraging. Termites emerged 298.9 million years ago. There about 3,106 species [2], these species are grouped into three, dampwood (mostly found in coniferous forest), drywood (found in hardwood forest) and subterranean termites (found in widely diverse area). There are 435 species found in Asia, 1000 species found in Africa, 50 species in North America, 400 species found in South America, 10 species found in Europe and 360 species found in Australia [3].

In caste system, the King mate with the queen, the king regulates the population of fertile female through pheromone [4]. The queen is primarily responsible for egg production and starting a colony. The soldier, just like humans, performs the duty of defense [5]. The soldiers are ranked; major, minor and nasutes [6]. The workers undertake most labor within the colony. Workers are responsible for food storage, foraging, brooding and nesting. They are also tasked with digestion of cellulose in food [7].

\section{Mystery and Potential of Termites}

\section{Behavioral mystery}

Most termites are blind. They communicate through chemicals, pheromone and mechanical cues such as vibration and touch [8]. The queen and king are monogamous and remain exclusive to each other till death. Only the queen and king perform nuptial flight (during which the virgin queens' mate with males and then land to start a new colony). When one colony encounters another colony during foraging, a species may commit suicide cramming (die to block the tunnel), the action settles the conflicts. Termites have cemetery pit, where dead termites are buried. 


\section{Nest/Mound}

Termites primary use faces, digested plant materials and soil as construction materials [9]. Nest are separated into three categories; epigeal (protruding above the soil surface) subterranean (underground nest) and arboreal (they are built with faucal elements and wood, they found on trees). The types of material(s) use depend on the category of nest or mound [4]. A nest consists of chimneys (air conditioning unit), surface conduct pinnacles and ridges. A nest can be as high as 8-9 meters $[2,10]$.

\section{Termites- organism/animals' interactions}

Termites nest provides good shelters and warmth to birds, lizards, snakes, Africa giant rat and scorpions. They also house other ants, such as Azteca ants, who assist termites to protect against predators $[2,11]$.

\section{A good delicacy}

In most developing countries, termites are highly valued and considered as a special delicacy. They are rich in protein, fat, vitamin and minerals [12].

\section{Medicinal purposes}

Figueirêdo et al., [13], findings indicated that about 45 species of termites from four families are used as both food sources and medicinal purposes. In Australia and some developing countries, termites are used commonly for medicinal purposes [13].

\section{Bioreactor}

Approximately 200 species of microbes live inside termites hidgut, releasing the nitrogen that was trapped inside wood and plant that they digested [14]. These make termites efficient bioreactors and have been reported to produce 2 liters of hydrogen from a single sheet of paper [15].

\section{Terme-robot}

Werfel et al., [16] reported that an autonomous robot was development as a result of an inspiration from termites.

\section{Architecture}

Many architectural works have been reported to be inspired by termites. Mick Pearce reported that he was inspired by termite in constructing East-Gate Centre building in Harare, Zimbabwe [17].

\section{Religion}

Some tribes in Indian, worship termite nest because of the cave complexity, multiplication of the mound without any visible external interference, their property and the ability of the nest to withstand sun, wind and rain [18-23].

\section{Conclusion}

Why then do we focus more on the wood destroying habits of these "small but mighty creature" endowed with great abilities and potentials? There is urgent need to study and focus more on beneficial sides of termites rather than developing "sledgehammers" (insecticides) to eliminate these great creatures. The problem of malnutrition in the world (especially developing countries) can be resolved if we look more into utilizing the food bank in termites. Just like animal husbandry and apiculture (rearing of bee), termites can be reared for food purposes, medicinal purposes, inspirational purposes and other purposes yet to be discovered. We want more from termites rather than just " destroyer of wood". Respect termite.

\section{Acknowledgement}

None.

\section{Conflict of Interest}

No conflict of interest.

\section{References}

1. Thomas ES (1954) Annotated, subject-heading bibliography of termites.

2. Krishna K (2015) Termite. Encyclopaedia Britannica.

3. Heather NW (1971) The exotic drywood termite Cryptotermes brevis (Walker) (Isoptera: Kalotermitidae) and endemic Australian drywood termites in Queensland. Australian Journal of Entomology 10(2): 134141.

4. Bignell DE, Roisin Y, Lo N (2010) Biology of Termites: a Modern Synthesis (1st ed.). Dordrecht: Springer.

5. Costa-Leonardo AM, Haifig I (2013) Termite communication during different behavioral activities in Biocommunication of Animals. Springer Netherlands, pp. 161-190.

6. Meek SP (1934) Termite Control at an Ordnance Storage Depot. American Defense Preparedness Association. pp. 159.

7. Matsuura K (2006) Termite-egg mimicry by a sclerotium-forming fungus. Proceedings of the Royal Society B: Biological Sciences 273(1591): 1203-1209.

8. Evans TA, Inta R, Lai JCS, Lenz M (2007) Foraging vibration signals attract foragers and identify food size in the drywood termite, Cryptotermes secundus. Insectes Sociaux 54(4): 374-382.

9. Noirot C, Darlington JPEC (2000) Termite Nests: Architecture, Regulation and Defence in Termites: Evolution, Sociality, Symbioses, Ecology. Springer, pp. 121-139.

10. Glenday Craig (2014) Guinness World Records 2014. pp. 33.

11. Santos PP, Vasconcellos A, Jahyny B, Delabie JHC (2010) Ant fauna (Hymenoptera, Formicidae) associated to arboreal nests of Nasutitermes spp: (Isoptera, Termitidae) in a cacao plantation in southeastern Bahia, Brazil. Revista Brasileira de Entomologia 54(3): 450-454.

12. Nyakupfuka A (2013) Global Delicacies: Discover Missing Links from Ancient Hawaiian Teachings to Clean the Plaque of your Soul and Reach Your Higher Self. Bloomington, Indiana: BalboaPress, pp. 40-41.

13. Figueirêdo RECR, Vasconcellos A, Policarpo LS, Alves RRN (2015) Edible and medicinal termites: a global overview, Journal of Ethnobiology and Ethnomedicine 11(29): 1-7.

14. Anklin-Mühlemann R, Bignell DE, Veivers PC, Leuthold RH, Slaytor M (1995) Morphological, microbiological and biochemical studies of the gut flora in the fungus-growing termite Macrotermes subhyalinus. Journal Insect Physiology 41(11): 929-940.

15. Hirschler B (2007) Termites' gut reaction set for biofuels. ABC News.

16. Werfel J, Petersen K, Nagpal R (2014) Designing Collective Behavior in a Termite-Inspired Robot Construction Team. Science 343 (6172): 754758. 
17. Tsoroti S (2014) What's that building? Eastgate Mall. Harare News.

18. Neoh KB (2013) Termites and human society in Southeast Asia. The Newsletter 30(66): 1-2.

19. Ramos-Elorduy J (2005) Insects: a hopeful food source. In: Paoletti MG, editor. Ecological implications of minilivestock. Enfield NH, USA: Science Pub, pp. 263-291.

20. Solavan A, Paulmurugan R, Wilsanand V, Sing AJA (2004) Traditional therapeutic uses of animals among trial population of Tamil Nadu. Indian Journal of Traditional Knowledge 3(2): 198-205.
21. Wilsanand V (2005) Utilization of termite, Odontotermes formosanus by tribes of South India in medicine and food. Nat Prod Rad 4: 121-125.

22. Solavan A, Paulmurugan R, Wilsanand V (2006) Effect of the subterranean termite used in the South Indian folk medicine. Indian J Tradit Knowledge 5: 376-9.

23. Solavan A, Paulmurugan R, Wilsanand V (2007) Antibacterial activity of subterranean termites used in South Indian folk medicine, Indian journal of traditional knowledge 6(4): 559-562. 